\title{
Sustaining the Low Income Family Participation in Drug Prevention Based Program: The Promising Factors
}

\author{
Ezarina Zakaria, Fauziah Ibrahim, Azzyikin Naser
}

To Link this Article: http://dx.doi.org/10.6007/IJARBSS/v11-i6/10239

DOI:10.6007/IJARBSS/v11-i6/10239

Received: 13 April 2021, Revised: 19 May 2021, Accepted: 28 May 2021

Published Online: 20 June 2021

In-Text Citation: (Zakaria et al., 2021)

To Cite this Article: Zakaria, E., Ibrahim, F., \& Naser, A. (2021). Sustaining the Low Income Family Participation in Drug Prevention Based Program: The Promising Factors. International Journal of Academic Research in Business and Social Sciences, 11(6), 1065-1075.

\section{Copyright: (c) 2021 The Author(s)}

Published by Human Resource Management Academic Research Society (www.hrmars.com)

This article is published under the Creative Commons Attribution (CC BY 4.0) license. Anyone may reproduce, distribute, translate and create derivative works of this article (for both commercial and non-commercial purposes), subject to full attribution to the original publication and authors. The full terms of this license may be seen at: http://creativecommons.org/licences/by/4.0/legalcode

Vol. 11, No. 6, 2021, Pg. 1065- 1075 


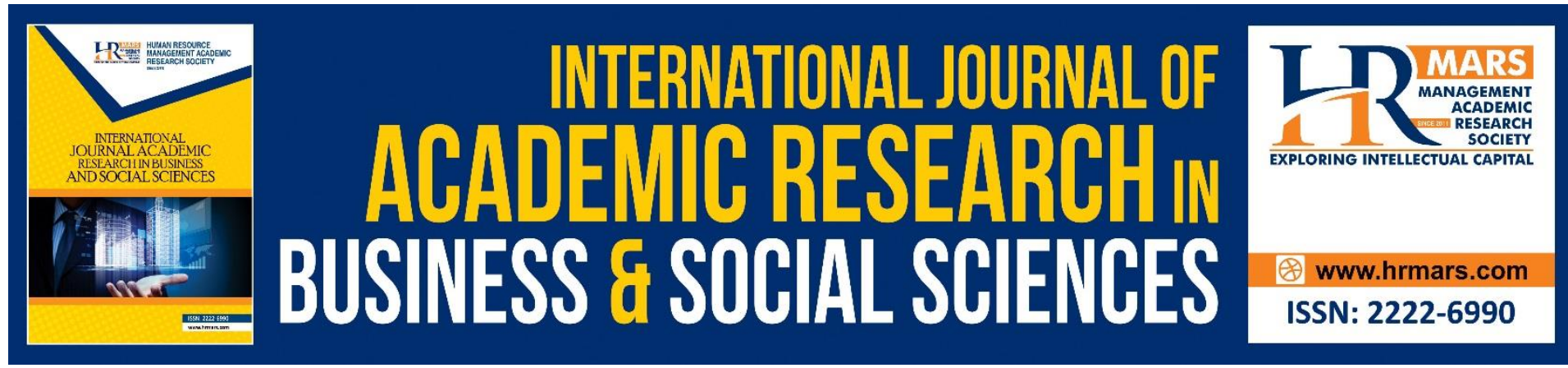

\title{
Sustaining the Low Income Family Participation in Drug Prevention Based Program: The Promising Factors
}

\author{
Ezarina Zakaria, Fauziah Ibrahim, Azzyikin Naser \\ Center for Research in Psychology and Human Well-Being, Faculty of Social Science and \\ Humanities, The National University of Malaysia, 43600 Bangi, Selangor, Malaysia \\ Email: ezaz@ukm.edu.my
}

\begin{abstract}
This article discusses findings from a survey study aimed at identifying the level of participation in a drug prevention education program among B40 families. It investigates four factors affecting their participation in the program, including family acceptance towards exdrug abusers, the readiness to participate in the program and the logistics and incentives access. A total of 295 families were randomly selected to participate in the study. Participation in the program by the families was found to be at a moderate level. The findings suggested there was a significant relationship between the participation of families in the drug prevention education program and acceptance towards ex-drug abusers, their readiness to participate, also logistics and incentives access. The findings reflect the decrease in the B40 family participation in a drug prevention education program due to the lack of logistics and incentives access provided by the program. The study also highlights the implications for improving agency networking through outsourcing the drug prevention education program.

Keywords: Family Involvement, Family Readiness, Logistic And Incentive, Drug Prevention Education Program, Low-Income Family
\end{abstract}

\section{Introduction}

The family environment has a great influence on the behavior of family members and is commonly documented as a protector against or trigger risk factor for drug abuse. Many researcher point out the importance of an integrated intervention-prevention program with the involvement of other social factors in the client system such as family, community, (Fauziah et al., 2013; National Drug Control Policy, 2011) and employers (Ezarina, et al., 2016). Previous studies have shown that family members were supposed to be involved in drug prevention programs in order to fulfil their role in the formation of a drug-free family environment. However, community-based prevention programs still received fewer encouraging responses, especially from the drug addict's family even though a big budget had been allocated and spent for that purpose.

In Malaysia, The National Anti-Drug Agency, also known as Agensi Anti Dadah Kebangsaan (AADK), plays an important role in combating drug addiction. In order to make Malaysia a drug-free country, AADK has undertaken various projects including organizing educational 
drug prevention programs for the community. Generally, the programs aim to provide awareness and education on prevention and drugs-related issues for children as early as school age. Drug prevention requires a stable social environment and comprehensive social system involvement at the micro, mezzo and macro levels (Włoch et al., 2014; Greenberg et al., 2005). Prevention programs at the micro level refer to individual and family levels which determine the success of prevention at the macro level, especially for the high-risk communities (Youth Risk Behavior Survey, 2013).

In fact, from the perspective of ecological theory, the family plays an important role in preventing drug abuse at every stage in the social system (Fauziah et al., 2012). However, the stage of planning and formation of a program for the at-risk family has its own challenges and should be recognized (Basic, 2015). The reception of and voluntary family involvement in any program related to drug abuse, such as drug prevention education programs, can be considered a challenge for organizers, as it involves the family members for a long period of time. To what extent the family want to get involved and try to engage is always questioned and may eventually cause the failure of the intervention in a wider radius. In fact, lack of parental involvement and support has been frequently documented and previous studies have confirmed the difficulties in attracting families to get involved and stay cooperative for a long time, especially in a prevention related program (St. Pierre and Kaltreider, 1997; St. Pierre et al., 1997). This not only applies to drug rehabilitation and intervention but also includes families in community-based rehabilitation programs such as healthcare management, physical fitness programs, and recidivism reduction.

Although many researchers are aware of the low response rate of family involvement in drug prevention interventions, research on the identification of the driving factors of noninvolvement is still under-represented. This is because previous studies tended to focus more on exploring how the families at high risk turn their own members into drug addicts, especially when their social environment plays an important role as an encouraging factor in drug abuse. Families can be considered at high risk when: i) family bonds between parents and children are loose, ii) there is low parental involvement in the children's activities, iii) there is poor management of family practices, iv) there is family history where members of the family have been involved in drugs, and v) parents are not aware of their child's addiction. According to Zainah, et al (2013); Miller et al (2013); Dever et al (2012); Mandara et al (2011), Lac et al (2011); and Luk et al (2010) scientific studies showed linkages with drug addicts among family members as risk factors, but still less focus was given to identifying the level and factors of family involvement, especially the Bottom 40 (B40-this refer to income groups in Malaysia, where B40 represents the bottom $40 \%$ of income earners) family participation in drug prevention education programs, even though it has already been documented by previous research.

Particular attention is given to the B40 families as previous studies have identified that large numbers of drug addicts and ex-convicts are from low socio-economic families (Fauziah, Suzana, et al., 2020; Fauziah, Ezarina, et al., 2020) as well as living in high-risk crime community surroundings. Even a study conducted by Ezhar et al. (2008) states that cultures of loitering and hanging out until late at night and substance abuse or smoking are three major social problems often associated with youths from low-income families, especially in the Perumahan Rakyat neighborhood. The results also show that youth from B40 family 
backgrounds are more at risk of being involved in social problems. Therefore, The National Anti-Drugs Agency (NADA or AADK) stipulates the selection criteria for the promotion of drug prevention education programs directly towards people living in high-risk community areas (high crime rates, social problems, and a high number of addicts). Based on the AADK resolution and the previous findings, it shows the linkage between the B40 community and families with drugs risk environments which help the researcher to justify why B40 families were selected for this study.

(https://www.adk.gov.my/pencegahan/keluarga-bebas-dadah).

Besides focusing on family acceptance and readiness to be involved in the research, this study also highlights another key dimension that is more likely to have a direct relationship with other factors - logistic rewards and incentives. According to Donnermeyer et al (1997) and Seal et al. (2003), the logistic rewards in non-monetary terms can be in the form of transportation availability, program implementation held near their residence, the availability of child-friendly spaces in order to provide a conducive environment for parents during talks and campaign sessions, and the program must not overlap with their workdays or shifts. The incentives were more centered on financial tokens, gifts or food. Incentives and access to the availability of logistics can be considered as rewards for the participants which is also documented in the studies by Laceteraa and Macisb (2010), Latkin and Knowlton (2006) and Butterfoss et al. (1996).

In particular, the present study aims to:

1. Identify the B40 family acceptance towards ex-addicts, readiness to participate, logistics and incentives, and family involvement in drug prevention based programs.

2. Study the predictive factors of B40 family involvement in drug prevention based programs.

\section{Methodology}

Respondent

The research was conducted using a qualitative method focused on the B40 group. A survey was conducted and 295 respondents among community members were selected using simple random sampling. The data collection was achieved by questionnaires and was analyzed using SPSS software. The results have been analyzed and are presented in the form of inferential and descriptive data.

\section{Instrument}

The questionnaire was formed by applying the concept of family readiness for involvement, which is related to the family readiness to get involved by the Community Readiness Scale (Oetting et al., 1995, Miller, 1990) or Community Readiness Scale for Prevention Programs (Donnermeyer et al., 1997) which combined the nine level community readiness model with five measurement dimensions. Testing tools were also applied to measure the level of family involvement as well as logistics and incentives. Construct on family acceptance of ex-addicts used the Social Acceptance Questionnaire (Arslan and Sahbaz, 2012).

The results of the reliability test using the Cronbach Alpha Model showed all questionnaire scores were moderately high for reliability and were good and effective. According to the questionnaire, the results showed that respondent involvement in a drugs prevention 
program for the family involvement scale had the highest alpha value which was .868 , followed by family readiness scale .831 , and logistics and incentives scale .829 . However, the family readiness scale represented the lowest value of .715 . In this study, the researcher set the significance level at $p<0.01$.

\section{Results}

\section{Results, Descriptive and Demographic Factors}

From the analysis of the survey data the study found that overall a total of 295 respondents were involved and they were divided according to the North Zone (Kedah and Penang), South Zone (Johor) and Centre Zone (Selangor and Perak). Table 1 shows the demographic profile of the research respondents.

\section{The Mean and Deviation distribution According to the Variables Studied}

Table 2 shows the mean and standard deviation distribution scores in total based on the variables studied. The results of the analysis found that logistics and incentives factors had the highest average mean score $(x=2.78)$, followed by family involvement readiness $(x=$ $2.77)$, social acceptance towards drug users $(x=2.52)$ and lowest was family involvement ( $x$ $=2.30$ ). This illustrates that the families of drug addicts had a high consensus on logistical and incentives factors.

\section{Objective 1}

Level of acceptance towards recovering drug addicts, willingness to participate, logistical access and level of family involvement in drug prevention education programs.

The results showed that 271 respondents (91.9\%) had acceptance of drug addicts at a moderate level followed by 13 respondents (4.4\%) had the lowest level of acceptance and only 11 respondents (3.7\%) who perceived acceptance at a high level. Results for logistics and incentives showed not many respondents were willing to attend drug prevention education programs without incentives from the organizers. Only 63 respondents $(21.4 \%)$ showed the highest willingness to be present without incentives, while at the moderate level were 209 respondents (70.8\%) and 23 respondents $(7.8 \%)$ at the lowest level.

The willingness of respondents to engage in drug prevention programs at a moderate level had a total of 249 participants (84.4\%) compared to only 36 (12.2\%) at a high level.

Apart from that, this research also studied the extent to which respondents had been involved in drug prevention education programs organized by the stakeholder. Based on the analysis of the level of involvement in the programs, the study showed that only 24 (8.1\%) had a high level of involvement, while a total of 174 (59.0\%) were moderate and 97 respondents (32.9\%) had a low level of involvement. This illustrates that only a few families agreed to engage in a program organized by drug-related agencies for their community.

\section{Objective 2}

The predictive factors of B40 family involvement in drug prevention education programs. The data analysis showed that there were two significant predictor variables, community readiness $(\beta=.517, t=11.09, p<.05)$ and incentives and logistics program $(\beta=-.262, t=$ $15.63, p<.05)$, which were identified as influencing factors in community involvement. The subsequent regression analysis result showed significantly that community readiness contributed $32.4 \%(r=.569)$ of variance change in community engagement score. The 
combination of both community readiness and incentives and logistics programs contributed $39 \%(r=.624)$ of variance change in community involvement $[F(2,292)=93.265, p<.05]$. A stepwise approach based on multiple regression analysis confirmed that the predictor variables of community readiness, also the logistics and incentives program were significant factors contributing to community involvement. The overall result indicated the higher the availability of logistics access and incentives, the greater the family involvement in drug prevention programs and vice versa.

Table 1: Respondent demographic profile.

Variables

Number (Percentage)

1. State

Johor

47 (15.9)

Selangor

99 (33.5)

Perak

49 (16.6)

Kedah

50 (16.9)

Penang

50 (16.9)

2. Ethnicity

Malay

$286(96.6)$

Chinese

$3(1.0)$

Indian

5 (1.7)

Others

$2(0.7)$

3 Religion

Islam

187 (96.6)

Buddhism

$1(0.3)$

Christian

$2(0.7)$

Hindu

5 (1.7)

4. Education Level

Never attended school

$6(2.0)$

Primary School

17

Malaysian Secondary Certificate

54 (18.3)

Malaysian Education Certificate

126

Malaysian Higher Education Certificate

$19(6.4)$

Vocational Certificate

$13(4.4)$

A-Level

$27(9.2)$

Bachelor Degree

$27(9.2)$

Others

$6(2.0)$

5. Occupation

Never worked

$88(29.8)$

Permanent

$145(49.2)$

Part-Time

$20(6.8)$

Others

$42(14.2)$

6. Marital Status

Married

$197(66.9)$

Divorced

$16(5.4)$

Separated but not divorced

Single

78 (26.4)

7. Family members, relatives and neighbors are involved in drugs 
Yes

No
$64(21.7)$

$231(78.3)$

$129(43.7)$

$166(56.3)$

9. Have you ever participated in any drug prevention programs?
Yes
122
No
$173(58.6)$

(41.4)

Table 2: Mean and standard deviation score distribution.

\begin{tabular}{lcc}
\hline & Mean & s.d. \\
\hline Logistics and incentives & 2.78 & .5255 \\
Family involvement readiness & 2.77 & .3517 \\
Acceptance towards former drug addicts & 2.52 & .3040 \\
Family involvement & 2.30 & .5802 \\
\hline
\end{tabular}

Table 3: Model summary: Influencing factors of community involvement.

\begin{tabular}{lllll}
\hline Model & $\mathrm{R}$ & R Square & Adjusted R Square & Std. Error of the Estimate \\
\hline 1 & $.569^{\mathrm{a}}$ & .324 & .321 & .47798 \\
2 & $.624^{\mathrm{b}}$ & .390 & .386 & .45479 \\
\hline
\end{tabular}

a. Predictors: (Constant), Community Readiness

b. Predictors: (Constant), Community Readiness, Incentive sand Logistics Programs

Table 4: Coefficients: Influencing factors of community involvement.

\begin{tabular}{|c|c|c|c|c|c|c|}
\hline \multirow[b]{2}{*}{ Model } & & \multicolumn{2}{|c|}{ Unstandardized Coefficients } & \multirow{2}{*}{$\begin{array}{l}\text { Standardized } \\
\text { Coefficients } \\
\text { Beta }\end{array}$} & \multirow[b]{2}{*}{$\mathrm{t}$} & \multirow[b]{2}{*}{ Sig. } \\
\hline & & $B$ & Std. Error & & & \\
\hline \multirow[t]{2}{*}{1} & (Constant) & -.301 & .222 & & -1.356 & .176 \\
\hline & $\begin{array}{l}\text { Community } \\
\text { Readiness }\end{array}$ & .939 & .079 & .569 & 11.841 & .000 \\
\hline \multirow[t]{3}{*}{2} & (Constant) & .739 & .280 & & 2.635 & .009 \\
\hline & $\begin{array}{l}\text { Community } \\
\text { Readiness }\end{array}$ & .854 & .077 & .517 & 11.099 & .000 \\
\hline & $\begin{array}{l}\text { Incentives and } \\
\text { Logistics Program }\end{array}$ & -.290 & .051 & -.262 & -5.626 & .000 \\
\hline
\end{tabular}

a. Dependent Variable: Community Involvement. 


\section{Discussion}

The research confirmed that family readiness and logistical factors, as well as a financial incentive, were able to encourage community participation in prevention programs for a long period of time. This was not only related to the families who were involved in drug rehabilitation intervention programs but also in community-based resurrection programs such as healthcare, physical fitness programs, crime reduction, and recidivism. The research findings were supported by Fauziah et al (2013); Miller et al (2013); St. Pierre and Kaltreider (1997) and St. Pierre et al. (1997). One of the biggest challenges during drug prevention intervention programs is the lack of information on the extent to which families and the community are ready to and want to participate. Research by Basic (2015) and Miller et al. (2012) emphasized the importance of family and community readiness as a major key to free people from the high-risk environment in order to succeed in any intervention programs.

Other than that, the family's ability to remain committed and supportive during drug prevention programs has become a long-term strength asset. According to Latkin and Knowlton (2005); Edwards et al (2000); and Butterfoss et al. (1996) two thing contributed to the effectiveness and large-scale of a program. First were participants being from various social systems such as the education system, social and security system, religious system, economic system, and the healthcare system. Second was the full utilization of internal resources and community strength. The community itself has their own inner strength and is always in a ready mode when changes are needed, especially when the community poses danger and risks to its own members. They can easily show their acceptance and readiness at a high level towards drug addicts. Therefore, it is important to identify at an early stage their level of family readiness before a program is carried out, this is the reason why preliminary research is important. Apart from that, the measure of their readiness will indicate whether the families remain unchanged or they are beginning to prepare themselves and show interest in participating actively in the prevention intervention at once.

In addition, a form of evaluation is needed to determine the attractions that can be used to encourage more commitment from the family to get involved. The results from this research accentuated the importance of attractions in the form of financial and logistical tokens. The B40 families were more likely to undergo the drug prevention education program if reward tokens are provided. This is especially referred to as a financial reward. The findings of the study are in parallel with the study conducted by Laceteraa and Macisb (2010), Latkin and Knowlton (2006) and Butterfoss et al. (1996). The Logistics and Incentive Scale used by this study confirms the importance of the following items, i) the distance between their residential area and the program location, ii) transportation and fare facilities availability, iii) the program does not overlap with their working days and shifts, especially for those who earn daily wages, iv) allowed to bring and participate together with their children, v) food is provided and vi) consolation money as a reward agreed by the respondents.

Incentive tokens are an attraction that is closely related to the family's social-economic status. This study has proven the tendency of B40 family involvement in drug prevention programs increases when logistical access and incentives are provided. A risk factor in the socioeconomic environment is not only directly related to the tendency for drug abuse misconduct but also contributes towards families lacking interest in the intervention programs. Some socioeconomic issues were identified as significant constraints on family involvement, such as poverty, low-cost housing and a high risk neighborhood environment, 
unemployment, no fixed income, stressful routines in family system, and time inadequacy to attend the program due to overlapping working hours with the overnight shift. In fact, families from B40 are more likely to take up the offer to participate if the organizer does not pay too much attention to giving incentive tokens and their logistic facilities.

Edwards et al (2000) stated the importance of having a solid starting point before any program is planned and developed. Especially when it comes to programs that are community-based, the success of the program depends heavily on the active participation of family members in the community. The starting point for Community A might not be the same as the starting point which should be highlighted in Community $\mathrm{B}$. This study showed that the B40 families in the community depended on incentive tokens and logistic facilities as their starting points to increase their involvement. The results also showed family readiness to participate in drugs prevention education programs was at the moderate to the lowest level. At this point, we believed the level of family attendance to the programs was directly related to the incentive tokens or financial rewards provided by the organizer. Also, the motivational level of the family-community needs to be addressed and is noteworthy. The effectiveness of the program relies strongly on the motivation of the family-community (Chavis and Wandersman, 1990), especially in accepting the ex-addicts and the intervention program itself. Family-community can be considered as a catalyst in family readiness to react. In any intervention program, the family and community are supposed to be social actors who should be involved in planning the goal of an intervention. Apart from the management agencies, families and communities are the end product that receive the benefits and are recognized as the owners of the interventions. Therefore, the study implied the need to improve the network among agencies (such as AADK and other non-governmental agencies) for encouraging and conducting drug prevention education programs with outsourcing such as:

i. To educate parents, schools, and Parents and Teachers Associations about drug-related prevention.

ii.To provide training and education to the respective communities through their own residents associations or community representatives.

Both outsourcing plans can be implemented by providing financial incentives and budget allocations from research grants to schools and residents associations.

\section{Conclusion}

In conclusion, research on family participation and acceptance and willingness towards exaddicts in this study is expected to provide specific input and indicators on how to encourage at risk family participation in drugs prevention education programs. The outcome of this study can be the initial step for future researchers. It is suggested that future research should explore and apply this study more on B40 family involvement influential factors, especially on their readiness, logistical rewards, and financial incentive factors. Other than that, this research also should be able to answer the extent to which financial rewards need to be continually compared to the application of pro-social values in themselves (intrinsic rewards) for families to fight drugs.

\section{Acknowledgement}

Appreciation and gratitude to The National University of Malaysia who sponsored this research study under grant code GGP-2017-049. 


\section{References}

Arslan, E., \& Sahbaz, U. (2012). A study to develop a scale for determining the social acceptance levels of special-needs students, participating in inclusion practices. Educational Research and Reviews, 7(29), 651-662.

Basic, J. (2015). Community Mobilization and Readiness: Planning Flaws which Challenge

Butterfoss, F. D., Goodman, R. M., \& Wandersman, A. (1996). Community Coalitions for Prevention and Health Promotion: Factors Predicting Satisfaction, Participation, and Planning. Health Education Quarterly, Vol. 23 (1), 65-79.

Communities That Care. (2010). The Communities That Care Youth Survey. Australia: Communities That Care Ltd.

Dever, B. V., Schulenberg, J. E., Dorkin, J. B., O’Malley, P. M., Kloska, D. D., \& Bachman, J. G. (2012). Predicting risk-taking with and without substance use: The effects of parental monitoring, school bonding, and sports participation. Prevention Science, 13(6), 605615.

Donnermeyer, J. F., Plested, B. A., Edwards, R. W., Oetting, G., \& Lawrence, L. (2009). Community readiness and prevention programs. Journal of the Community Development Society. 28 (1) : 65-83.

Edwards, R. W., Jumper-Thurman, P., Plested, B.A., Oetting, E. R., \& Swanson, L. (2000). Community readiness: Research to practice. Journal of Community Psychology, 28(3), 291-307.

Ezarina, Z., Fauziah, I., Salina, N., Norjana, S. \& Mohd, N. M. S. (2016). Perbandingan peluang pekerjaan oleh majikan kepada bekas penagih dadah di Malaysia. Journal of Southeast Asian Studies (JATI), 21, 124-141.

Ezhar,T., Jusang, B., Ismail, Z. \& Muhammad Rezal, H. (2008). Faktor penglibatan remaja daripada keluarga berpendapatan rendah di bandar dalam masalah sosial. Jurnal Pembangunan Belia Malaysia, 1, 165-182. ISSN 1985-9422.

Fauziah, I., Suzana, M. H., Ezarina, Z., Salina, N., Norulhuda, S.,Khadijah, A., Nasrudin, S. \& Mohd Suhaimi, M. (2020). Drug abuse and the involvement of prisoners in street crimes. International Journal of Psychosocial Rehabilitation, 24 (04), 4508 - 4516.

Fauziah, I., Ezarina, Z., Salina, N., Norulhuda, S., Nazirah, H. \& Siti, M. M. (2020). Social pressure among

former drug addicts after discharged from drug rehabilitation centre. International Journal of Psychosocial Rehabilitation, 24(04), 4517-4525.

Fauziah, I., Ezarina, Z., Salina, N., Norulhuda, S., \& NorJana, S. (2013). Pengguna dadah wanita di Malaysia: Pengalaman penagihan dan hubungan kekeluargaan. Jurnal Teknologi (Social Sciences), 67(1), 17-25.

Fauziah, I., Khadijah, A., Noremy, M.A., Sarnon, N., Lukman, Z. M., Mohamad, S.M., Subhi, N., Nen, S. \& Suzana, M. H. (2012). The role of family towards current adolescence challenges: Drug prevention and living without drugs. The Social Sciences, 7(2), 341-345.

Greenberg, M. T., Feinberg, M. E., Brendan, J., Gomez, B.J. \& Osgood, D.W. (2005). Testing a community prevention focused model of coalition functioning and sustainability: A comprehensive study of communities that care in Pennsylvania. In Stockwell, T., Gruenewald, P., Toumbourou, J.W., Loxley, W. (Editors). Preventing harmful substance use: The evidence based for policy and practice. Wiley: London.

Lac, A., Unger, J.B., Basanez, T., Ritt-Olson, A., Soto, D.W., \& Baezconde-Garbanati, L. (2011). Marijuana use among Latino adolescents: Gender differences in protective familial factors. Substance Use and Misuse, 46, 644-655. 
Laceteraa, N., \& Macisb, M. (2010). Do all material incentives for pro-social activities backfire? The

Latkin, C. A., \& Knowlton, A. R. (2006). Micro-social structural approaches to HIV

prevention: A social ecological perspective. AIDS Care. Psychological and Socio-medical Aspects of AIDS/HIV , 17, $103-113$.

Luk, J. W., Farhat, T., lannotti, R. J., \& Simons-Morton, B. G. (2010). Parent-child communication and

substance use among adolescents: Do father and mother communication play a different role for sons and daughters?. Addictive Behaviors, 35(5), 426-431.

Mandara, J., Rogers, S. Y., \& Zinbarg, R. E. (2011). The effects of family structure on African American adolescents' marijuana use. Journal of Marriage and Family, 73(3), 557-569.

Miller, S. M., Siegel, J.T., Hohman, Z., \& Crano, W. D. (2013). Factors mediating the association of the regency of parent's marijuana use and their adolescent children's subsequent initiation. Psychology of Addictive Behaviors, 27(3), 848-853.

Miller, M. A. (1990). Exploring rural community readiness for participation in community and natural resources development extension education program. In: Donnermeyer et al. (1997). Community readiness and prevention programs. Journal of the Community Development Society, 28(1), $65-83$.

Miller, B. A., Aalborg, A. E., Byrnes, H. F., Bauman, K., \& Spoth, R. (2012). Parent and child characteristics related to chosen adolescent alcohol and drug prevention program. Health Education Research, 27(1), 1-13.

National Drug Control Policy. (2011). Preventing substance abuse in our communities. Fact Sheet. Office of National Drug Control Policy.

Oetting, E. R., Donnermeyer, J. F., Plested, B. A., Edwards, R. W., Kelly, K., \& Beaurais, F. (1995). Assessing community readiness for prevention. International Journal of the Addictions, 30(6), $659-683$.

O'Mahony, P. (2009). The risk factors prevention paradigm and the causes of youth crime: A deceptively useful analysis?. Youth Justice, 99(2), 99-114.

Seal, K. H. Kral, A. H., Lorvick, J., McNees, A., Gee, L., \& Edlin, B. R. (2003). A randomized controlled trial of monetary incentives vs. outreach to enhance adherence to the hepatitis B vaccine series among injection drug users. Drug and Alcohol Dependence, 71(2), 127-131

St. Pierre, T. L., \& Kaltreider, D. L. (1997). Strategies for involving parents of high-risk youth in drug prevention: A three-year longitudinal study in Boys and Girls Clubs. Journal of Community Psychology, 25(5), 473-485.

St. Pierre, T. L., Mark, M. M., Kaltreider, D. L., \& Aikin, K. J. (1997). Involving parents of highrisk youth in drug prevention: A three-year longitudinal study in Boys and Girls Clubs. Journal of Early Adolescence, 17(1), 21-50.

Włoch, K., Książek, P., Warchoł-Sławińska, E., Drop, B., \& Fałkowski, A. (2014). Drug addiction: relationship to the Ecological Health Model and social interactions. Health and Wellness, 4, $231-237$.

Zainah, A. Z., Rohany, N., Asmawati, D., Rozainee, K., Fatimah, Y., \& Siti Hajar, M. Y. (2013). Kefungsian keluarga, pengherotan kognitif dan resilien dalam kalangan klien Cure and Care Rehabilitation Centre (CCRC) dan Klinik Cure and Care (C\&C). Jurnal Psikologi Malaysia, 27, 137-149. 